\title{
Increased antitumor efficiency and reduced negative side effects of 4-thiazolidinone derivatives in complexes with PEG-containing polymeric nanocarrier
}

\author{
L. I. Kobylinska ${ }^{1}$, N. R. Skorohyd ${ }^{2}$, O. V. Klyuchivska ${ }^{2}$, N. Ye. Mitina ${ }^{3}$, \\ A. S. Zaichenko ${ }^{3}$, R. B. Lesyk ${ }^{1}$, B. S. Zimenkovsky ${ }^{1}$, R. S. Stoika ${ }^{2}$ \\ ${ }^{1}$ Danylo Halytsky Lviv National Medical University \\ 69, Pekarska Str., Lviv, Ukraine, 79010 \\ 2 Institute of Cell Biology, NAS of Ukraine \\ 14/16, Drahomanov Str., Lviv, Ukraine, 79005 \\ ${ }^{3}$ Lviv Polytechnic National University \\ 12, S. Bandery Str., Lviv, Ukraine, 79013 \\ lesya8@gmail.com,Kobylinska_Lesya@meduniv.lviv.ua
}

\begin{abstract}
Aim. To study an anticancer activity and to measure cytological and enzymatic indicators of general toxicity of 4-thiazolidinone-based compounds (Les-3288, Les-3833) in the NK/Ly lymphoma grafted to BALB/C mice. Methods. BALB/C mice were implanted with the ascitic NK/ Ly lymphoma and treated for 14 days with 4-thiazolidinone derivatives - Les-3833 $(2.5 \mathrm{mg} / \mathrm{kg}$ of bodyweight), Les-3288 (5 mg/kg of bodyweight), a complex of Les-3833 with the polymeric nanocarrier Les-3833+PNC (2.5 mg/kg of bodyweight) in water, and doxorubicin (1 mg/kg of bodyweight) used as a positive control. The lymphoma development was monitored by measuring the amount of ascitic fluid in the treated mice. The effects of the applied compounds were checked after 35 days of tumor growth. Results. A distinct decrease in the amount of the ascite fluid with lymphoma cells was revealed in the treated mice, while a 1.5-fold increase of its amount was detected in the untreated mice of control group. The 4-thiazolidinone derivatives demonstrated much less toxicity, and erythrocytes count stayed normal after 21 days of animal treatment. The development of NK/Ly lymphoma led to an increase in the neutrophils number, while the applied anticancer compounds reduced it significantly. Les-3833 and Les-3288 did not affect the number of lymphocytes over the normal level. The activity of aspartate and alanine aminotransferases in blood serum was elevated on the 14 day of treatment, and returned to the normal level on the 21 day. Conclusion. Novel 4-thiazolidinones Les-3833 and Les-3288 are effective in the treatment of NK/Ly lymphoma grafted to BALB/C mice. These derivatives induced had limited negative side effects in the treated mice.
\end{abstract}

Ke y w or d s: 4-thiazolidinones, murine lymphoma NK/Ly, BALB/C mice, glioma C6 cells, apoptosis

(C) 2018 L. Kobylinska et al.; Published by the Institute of Molecular Biology and Genetics, NAS of Ukraine on behalf of Biopolymers and Cell. This is an Open Access article distributed under the terms of the Creative Commons Attribution License (http://creativecommons.org/licenses/by/4.0/), which permits unrestricted reuse, distribution, and reproduction in any medium, provided the original work is properly cited 


\section{Introduction}

Chemotherapy is the main treatment modality for many tumors, nevertheless severe sideeffects of chemotherapeutic agents reduce the clinical efficacy of large number of anticancer drugs that are currently being used. Therefore, there is continuous need to develop alternative or synergistic anticancer drugs with reduced or minimal side-effects. Currently, the research in cancer chemotherapy also focuses on studying anticancer agents at the molecular level. To evaluate the effectiveness of new drugs, it is important to study the interruption and dysregulation of the cell cycling and cell death processes not only in the tumor development, but also in the cardiovascular system, liver, kidney, brain, and the immune system that will characterize general toxicity of the drug (1).

High lipophilicity and low water-solubility are additional drawbacks of many chemotherapeutics, including newly developed small molecules as potential anticancer agents. To overcome these drawbacks and improve waterinsoluble anticancer drugs, a high concentration of surfactants and co-solvents is used. However, they can also produce their own adverse side effects, thus hindering the action of such anticancer drugs [2]. Many highly active and promising new agents were rejected because of their low solubility [3].

The nanocarrier systems (lipid-based, polymer-based, albumin-based, others) have been studied extensively for encapsulation and delivery of both existing and new insoluble anticancer drugs [4]. Nanocarriers offer additional advantages of enhanced tumor accumulation, reduce systemic toxicity, and improve therapeutic effectiveness. The development of nanoparticles that carry drugs to target sites in the body promises a safer and more effective drug delivery [5]. The surface modification of drug nanocarriers to enhance their compatibility with the body and to improve drugs' ability to target desired cells and tissues is of importance, but remains an unmet challenge. These nanoparticles can thus evade the body's immune system for extended periods of time, continuing to circulate unnoticed through the bloodstream, effectively delivering their drug payload [6].

The polymer-based therapeutics were established as an innovative and reliable approach because of their ability to conjugate with a variety of molecules and compounds (e.g., proteins, enzymes, nanoparticles, liposomes, low molecular weight drugs) [7]. The polyethylene glycol (PEG), a water-soluble and biocompatible polymer, is the most commonly used non-ionic polymer in the polymerbased drug delivery [4]. PEG has been studied extensively as a drug-delivery vehicle, because it is soluble in both organic and hydrophilic solvents. Unlike many other synthetic polymers, PEG is relatively hydrophilic. PEG can be conjugated to other polymers (i.e., PEGylation) to make them less hydrophobic. A greater surface hydrophilicity enables cell adhesion and proliferation on biomaterial scaffolds by preventing protein adsorption [8]. Thus, PEG availability in the polymeric nanocarriers (PNC) is a useful characteristic that makes possible the] formation of micelles containing hydrophobic compounds in the hydrophilic medium that is present in the organism.

There is still no consensus about the optimal particle size for enhancing in vivo action and 
clinical biodistribution. The nanocarriers of less than $100 \mathrm{~nm}$ diameter are usually preferred. However, an excessive size reduction can also be a disadvantage because the nanoparticles smaller than $50 \mathrm{~nm}$ are subjected to a higher uptake in liver and spleen that leads to the increasing liver toxicity. The nanoparticles smaller than $5 \mathrm{~nm}$ are removed by the kidney [9].

The aim of this work was to study the treatment effects and general toxicity (cytological and enzymatic) of novel 4-thiazolidinone derivatives Les-3288 and Les-3833 in experimental tumor model - NK/Ly lymphoma grafted to $\mathrm{BALB} / \mathrm{C}$ mice; the water preparations of these compounds dispersed and stabilized by an amphiphilic polymer in comparison with the drugs in free form were used for induction of apoptosis in rat glioma cells of C6 line and treatment of NK/Ly lymphoma grafted to $\mathrm{BALB} / \mathrm{C}$ mice.

\section{Materials and Methods}

The 4-thiazolidinone derivatives Les-3288 (5-bromo-3-\{2-[5-(4-methoxyphenyl)-3-phenyl-4,5-dihydropyrazol-1-yl]-4-oxo-4,5- dihydro-1,3-thiazol-5-ylidene \}-2,3-dihydro- $1 \mathrm{H}$ indol-2-one) and Les-3833 (5-bromo-3-\{2-[5(4-methoxyphenyl)-3-naphthalen-2-yl-4,5dihydropyrazol-1-yl]-4-oxo-4,5-dihydro-1,3thiazol-5-ylidene $\}$-2,3-dihydro- $1 H$-indol2-one) were designed as promising anticancer agents as we described earlier [10]. Before using we dissolved the investigated compounds in the dimethylsulfoxide (DMSO, Arterium, Ukraine), after that dissolved in distilled water. The final concentration of the DMSO was kept less $0.1 \%$. Doxorubicin was obtained from Pfizer (New York, NY, USA).
The synthesis of PNC was carried out as it was described earlier $[11,12]$. The composition of PNC was determined from the results of elemental and functional analyses. The assumed comb-like copolymer structure is presented in Fig.1. It is a water soluble weakly surface active polymeric surfactant forming micelle-like structures in water solution. The diameter of PNC particles was $60-100 \mathrm{~nm}$, as determined by a transmission electron microscopy and confirmed by the dynamic light scattering on Zetasizer Nano (Malvern Instruments $\mathrm{GmbH}$, Stuttgart, Germany) and photon cor-
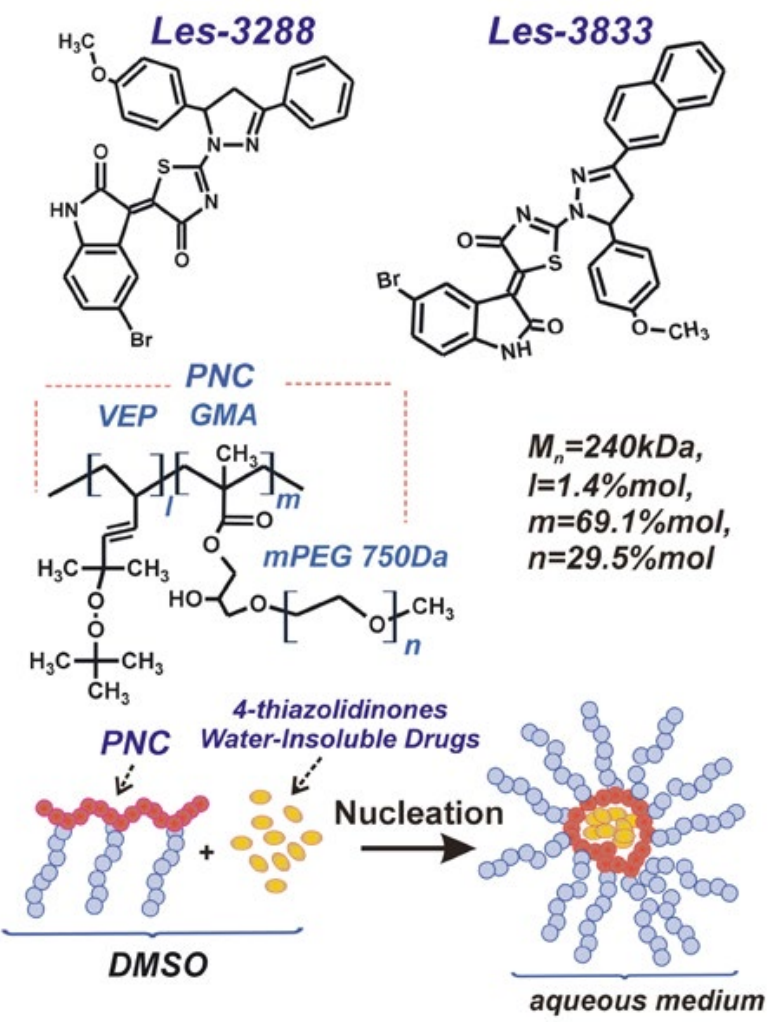

Fig. 1. The structure of drugs and amphiphilic polymer; the scheme of the drug particle nucleation and stabilization with polymeric nanocarrier (PNC). 
relation spectra using non-invasive back scatter technology [11].

The solutions of amphiphilic polymer and 4-thiazolidinone derivatives in DMSO were mixed in the flask and added drop by drop to physiological solution at the stirring. $0.045 \mathrm{~g}$ of PNC were dissolved in DMSO, $0.0015 \mathrm{~g}$ of the drug (Les-3288 or Les-3833) were dissolved in $0.25 \mathrm{ml}$ of DMSO. The solution of PNC and the drug was mixed and added to $4.25 \mathrm{ml}$ of saline solution ( $1 \%$ aqueous $\mathrm{NaCl}$ solution) and subjected to ultrasonic dispersion (10 seconds). As a result the nanoparticles of water insoluble 4-thiazolidinone were nucleated in the micelle-like structures of polyamphiphil used as a soft template and stabilized by the polymer molecules adsorbed on the particle surface. Highly stable water dispersions of 4-thiazolidinone derivatives $(0.3 \mathrm{mg} /$ $\mathrm{mL}$, drug/polymer weight ratio $1 / 30$ ) are formed. The dispersions were stable and did not change the size in the range $60-150 \mathrm{~nm}$ and PDI $=0.05$ during 3 months. The size of the micelles was measured using dynamic light scattering technique Zetasizer Nano ZS (Malvern Instruments $\mathrm{GmbH}$, Stuttgart, Germany) instruments and by photon correlation spectroscopy using the Non-Invasive Back Scatter technology (NIBS) at $298 \mathrm{~K}$ and confirmed by transmission electron microscopy (JEM-200Aб JEOL, Japan) [11, 12].

The rat glioma cells of C6 line were obtained from Cell Culture Collection at the Institute of Molecular Biology and Genetics, National Academy of Sciences of Ukraine (Kyiv, Ukraine). The glioma C6 cells were cultured in Dulbecco's modified Eagle's medium (DMEM, Sigma, USA) supplemented with $10 \%$ fetal bovine serum (Sigma, USA).
The cells were grown up in the $\mathrm{CO}_{2}$-incubator at $37^{\circ} \mathrm{C}, 5 \% \mathrm{CO}_{2}$ and $95 \%$ humidity. The reseeding of cells was carried out at a ratio of $1: 5$ once every $2-3$ days.

The glioma C6 cells were seeded on glass microscopic slides in the 24-well plates (Greiner bio-one, USA). The substances were added in different concentrations $24 \mathrm{~h}$ after cell seeding. The material of cell nucleus was stained with the DNA-specific fluorescent dye Hoechst 33342 (Sigma, USA). This fluorochrome was added to cultured cells at $0.2-$ $0.5 \mu \mathrm{g} / \mathrm{ml}$, and the cells were incubated for 20-30 min. The living, apoptotic and necrotic cells were viewed under the inverted light microscope Biolam (LOMO, Russian Federation). The images were processed with the fluorescent Zeiss microscope (Carl Zeiss, Germany) using AxioImager A1 camera, by 400 times magnification in the relevant sections of the excitation and emission.

All animal experiments were conducted keeping to European Convention on Protection of Vertebrate Animals (Strasbourg, 1986) and the corresponding Law of Ukraine (N944, 14.12.2009) [13].

The mice weighing 18-25 g were kept at a temperature of $22 \pm 2{ }^{\circ} \mathrm{C}$ and with photocycle

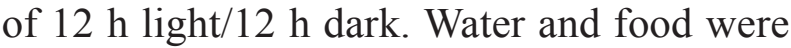
provided ad libitum. NK/Ly ascite lymphoma was implanted to $\mathrm{BALB} / \mathrm{C}$ mice. The ascites tumor was supported by transferring 0.2 $0.3 \mathrm{~mL}$ of ascitic fluid (20-30 x $10^{6}$ cells) from donor mouse into the abdominal cavity of the recipient mouse. The viability and number of the cells stained with $0.05 \%$ Trypan Blue were checked by cell counting in the haemocytometric chamber (PJSC "Skloprylad", Ukraine). The vitality of NK/Ly lymphoma cells used 
for transplantation was not less than $98 \%$. Ascites from the tumor-bearing mice were obtained and transplanted on the 7-8th day after the inoculation. The next day after tumor implantation, the studied substances were injected daily 5 times intraperitoneally. The dose was $10 \%$ of maximal injected dose in the experiments when $\mathrm{LD}_{50}$ was defined. Doxorubicin (positive control) was applied in dose $1 \mathrm{mg} / \mathrm{kg}$ of body weight, Les-3833 $2.5 \mathrm{mg} / \mathrm{kg}$, and Les-3288 - $5 \mathrm{mg} / \mathrm{kg}$, Les$3833+\mathrm{PNC}-1 \mathrm{mg} / \mathrm{kg}$. Here and elsewhere, the dose of the Les-3833 compound is indicated using either free compound or its complex with PNC. The ratio Les-3833 to the PNC in complex equaled 1:30. Therapeutic effect of drugs was checked up to 30 days of tumor growth. During the experiment the animals were weighed every day, and lymphoma growth was monitored by measuring the volume of the ascitic fluid in treated mice.

For blood sampling, a small part of mouse tail was cut with pumping $\sim 100 \mu \mathrm{l}$ of blood in a test tube, followed by immediate disinfection of a wound with $70 \%$ alcohol. For counting red blood cells, $5 \mu \mathrm{l}$ of blood were dissolved in $5 \mathrm{ml}$ of isotonic $\mathrm{NaCI}$ solution $(1: 1,000$ dilution), while for leukocyte, $5 \mu \mathrm{l}$ of blood were dissolved in $95 \mu 1$ of $3 \%$ acetic acid solution (1:20 dilution). Erythrocytes and leukocytes were counted under the Evolution 300 Trino microscope (Delta Optical, Mińsk Mazowiecki, Poland) and calculated by standard formulas, described in [14]. For blood smear preparation, $3 \mu \mathrm{l}$ of blood were put at the edge of a slide, and then spread for $1.5 \mathrm{~cm}$ using another narrow polished slide, placed at a $45^{\circ}$ angle. The obtained smears were dried at room temperature, then fixed with absolute methanol, and later rehydrated by subsequent washing in ethanol solutions with decreasing concentration $(96 \%, 75 \%, 50 \%, 25 \%$, $12.5 \%$ ). Finally, the smears were washed with distilled water, stained with Giemsa dye and air-dried, after which they were ready for analysis of leukogram. Counting of leukocytes was performed under Evolution 300 Trino microscope (Delta Optical, Mińsk Mazowiecki, Poland) using $90 \times$ oil immersion objective. Cell counting was always done using the same system - half of cells were counted in the upper half part of the smear, and the rest $50 \%$ of cells were counted on the lower part of the smear. A percentage of certain types of white blood cells in each smear was determined after counting of at least 300 cells.

To measure the aspartate aminotransferase activity (AST), $10 \mu \mathrm{l}$ of blood serum were mixed with $100 \mu$ l of substrate solution $(2 \mathrm{mM}$ a-ketoglutaric acid; $0.2 \mathrm{M} \mathrm{D,L-aspartate} \mathrm{in}$ $0.1 \mathrm{M}$ phosphate buffer $\mathrm{pH}$ 7.4), while in control tube $10 \mu 1$ of distilled water were added instead of blood serum. The tubes were placed for $60 \mathrm{~min}$ at $37^{\circ} \mathrm{C}$, and then $100 \mu \mathrm{l}$ of $1 \mathrm{mM}$ solution of 2,4-dinitrophenylhydrazine were added to the samples and left for $20 \mathrm{~min}$ at RT. Then $1 \mathrm{ml}$ of $0.4 \mathrm{M}$ sodium hydroxide solution was added to each sample for extra $10 \mathrm{~min}$, and optical density of samples was measured using ThermoSpectronic spectrophomometer (Helios, Great Britain) at $540 \mathrm{~nm}$ wavelength. For determination of alanine aminotransferase (ALT) activity, the procedure was identical except for substrate solution ( $2 \mathrm{mM}$ a-ketoglutaric acid; 0.2 M D,L-alanine in phosphate buffer $\mathrm{pH}$ 7.4).

All experiments were repeated 3 times. Statistical analysis of the data due to a low 
number of samples per group $(n=6)$ was conducted in GraphPad Prism software (GraphPad Software Inc. La Jolla, CA, USA) using non-parametric tests (2-way ANOVA with Bonferroni post-hoc tests, which compare replicate values by rows). Statistical significance was set at $\mathrm{P} \leq 0.05$.

\section{Results}

Morphological changes in rat glioma C6 line cells under the treatment with Les-3288 and its complex with polymeric nanocarrier

The microscopic study of morphological changes in the rat glioma C6 cells under the treatment with applied compounds in $0.1,0.5$ and $1.0 \mu \mathrm{g} / \mathrm{ml}$ doses demonstrated that Les3833 in $1 \mu \mathrm{g} / \mathrm{ml}$ dose caused the most drastic changes in the cell intactness, namely a diminution in cell density in vitro, a decrease in cell size, probably due to apoptotic condensation of cell body, and appearance of cell debris (Figure 2, table 1). At the action of free and PNC-stabilized forms of Les-3288, there were no essential differences in chromatin condensation estimated by DAPI staining, loss of cellular appendages, a decrease in the cellular size, and the amount of cell debris (Figure 2, table 1). One can see cytodestruction caused by Les-3288 and Les-3833, however, there was a distinct decrease in the number of glioma cells at their treatment with the water based complex Les-3288+PNC comparing with the number of glioma cells at their treatment with a free form of Les-3288 (Figure 2). Noteworthy, PNC itself did not cause drastic changes in the morphological intactness of glioma cells.

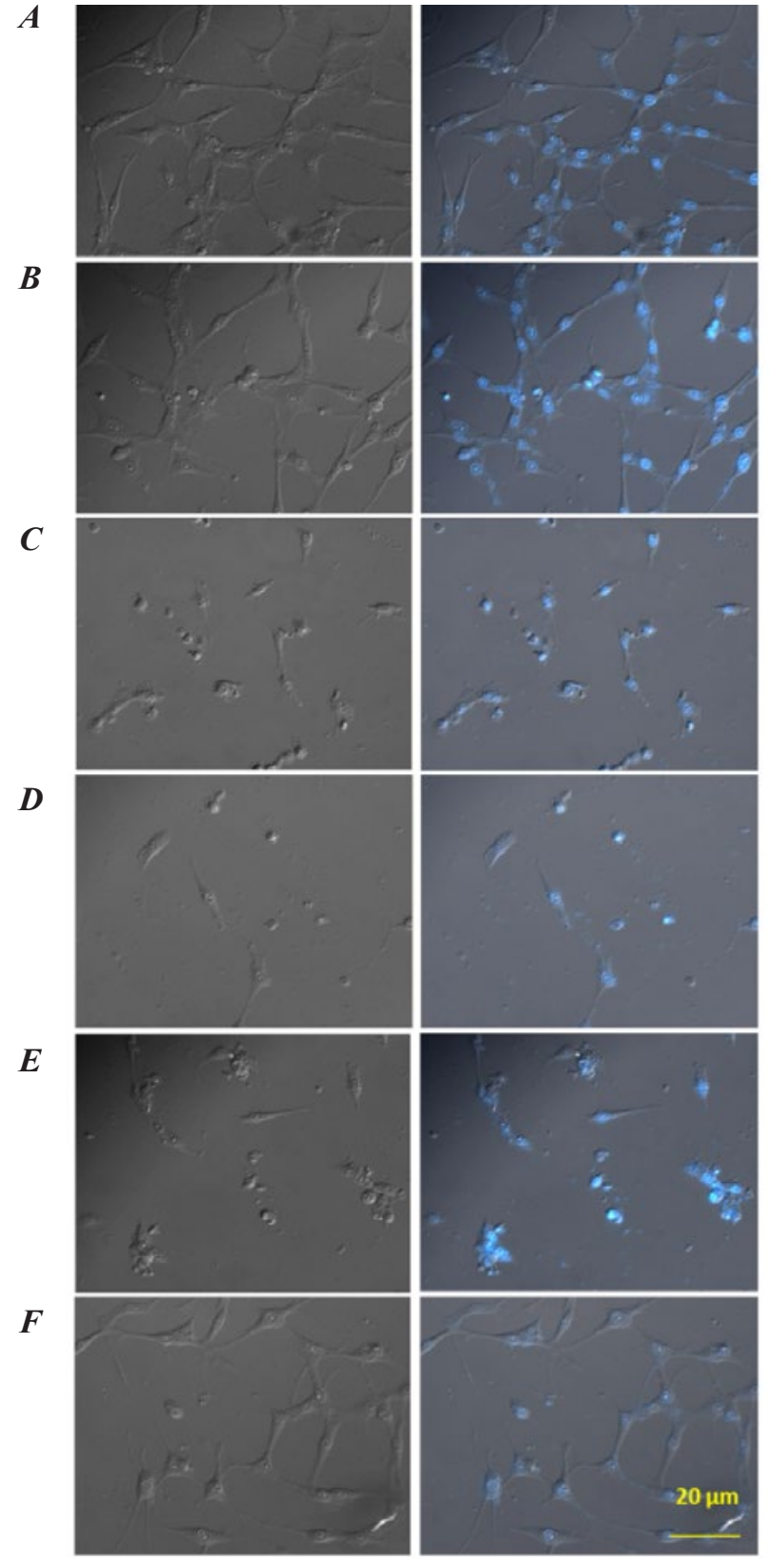

Fig. 2. DIC (left) and combined DIC-fluorescent (Hoechst-33342, right) microscopic images of rat glioma C6 cells treated for $24 \mathrm{~h}$ with the studied compounds: $A$ - control (untreated cells); $B$ - polymeric nanocarrier (PNC), $1 \mu \mathrm{g} / \mathrm{ml} ; C-0.5 \mu \mathrm{g} / \mathrm{ml}$ Les-3833; $D$ - complex PNC with Les-3833 (0.5 $\mu \mathrm{g} / \mathrm{ml}) ; E$ - Les-3288 (0.5 $\mu \mathrm{g} /$ $\mathrm{ml}) ; F$ - complex PNC with Les-3288 $(0.5 \mu \mathrm{g} / \mathrm{ml})$. 
Table 1. The morphological changes in the rat glioma $\mathbf{C 6}$ cells caused by the treatment with compounds Les-3288 and Les-3833 $(0.1 \mu \mathrm{g} / \mathrm{ml}, 0.5 \mu \mathrm{g} / \mathrm{ml}$ and $1.0 \mu \mathrm{g} / \mathrm{ml})$ and their complexes with PNC

\begin{tabular}{|c|c|c|c|c|c|}
\hline \multicolumn{2}{|c|}{ Samples $(\mu \mathrm{g} / \mathrm{ml})$} & $\begin{array}{l}\text { Chromatin } \\
\text { condensation } \\
\text { (DAPI) }\end{array}$ & $\begin{array}{l}\text { Loss of } \\
\text { appendage cells }\end{array}$ & $\begin{array}{l}\text { Decrease in cell } \\
\text { size }\end{array}$ & Cell debris \\
\hline \multicolumn{2}{|l|}{ Control } & $+/-$ & - & - & $+/-$ \\
\hline \multicolumn{2}{|l|}{$\mathrm{PNC}$} & $+/-$ & - & - & $+/-$ \\
\hline Les-3833 & $\begin{array}{l}0.1 \\
0.5 \\
1.0\end{array}$ & $\begin{array}{c}+/- \\
+ \\
++\end{array}$ & $\begin{array}{c}+/- \\
+ \\
+++\end{array}$ & $\begin{array}{c}+/- \\
+ \\
+++\end{array}$ & $\begin{array}{c}+ \\
+++ \\
++++\end{array}$ \\
\hline Les-3833 + PNC complex & $\begin{array}{l}0.1 \\
0.5 \\
1.0\end{array}$ & $\begin{array}{l}+/- \\
++ \\
++\end{array}$ & $\begin{array}{c}+ \\
++ \\
+++\end{array}$ & $\begin{array}{c}+ \\
++ \\
+++\end{array}$ & $\begin{array}{c}+ \\
++ \\
++++\end{array}$ \\
\hline Les-3288 & $\begin{array}{l}0.1 \\
0.5 \\
1.0\end{array}$ & $\begin{array}{l}+ \\
+ \\
++\end{array}$ & $\begin{array}{c}+ \\
++ \\
++++\end{array}$ & $\begin{array}{c}+ \\
++ \\
++++\end{array}$ & $\begin{array}{c}+ \\
+++ \\
++++\end{array}$ \\
\hline Les-3288 + PNC complex & $\begin{array}{l}0.1 \\
0.5 \\
1.0\end{array}$ & $\begin{array}{c}+/- \\
+ \\
++\end{array}$ & $\begin{array}{c}+ \\
++ \\
+++\end{array}$ & $\begin{array}{c}+ \\
++ \\
+++\end{array}$ & $\begin{array}{c}+ \\
++ \\
++++\end{array}$ \\
\hline
\end{tabular}

“"“" no effect, "“+/_" weak effect, "++++" strong effect.

Survival and tumor growth in mice bearing $N K /$ Ly lymphoma under the treatment with 4-thiazolidinone derivatives (Les-3833 and Les-3288) and Doxorubicin (positive control)

As one can see in the figure 3 , the Dox and water based form of Les-3833 stabilized polymeric surfactant demonstrated the best treatment effects towards NK/Ly lymphoma-bearing mice whereas the antitumor effect of complex Les-3833+PNC towards murine NK/Ly lymphoma was comparable with the effect of doxorubicin ("golden standard" in cancer chemotherapy). The antitumor effect of Les-3288 on lymphoma-bearing mice was weaker than that of Dox and Les-3833. After tumor inoculation in mice and the treatment with complex Les-3833+PNC or Dox, the animals stayed with a reduction of lymphoma for more than 40 days of the experiment (Fig. 3, 35 days).

Such effects of animal treatment correlated with a drug-induced decrease in volume of the ascite fluid that was elevated by 1.5 times in the untreated mice (control group) (figure 4). Under the action of Dox, Les-3833 and Les3288 , a similar change (decrease) was found.

Activity of aspartate and alanine aminotransferases in blood serum of mice bearing NK/Ly lymphoma under the treatment with 4-thiazolidinone derivatives (Les-3833 and Les-3288) and Doxorubicin (positive control)

Aspartate and alanine aminotransferases are considered as biochemical parameters of liver damage $[15,16]$. It was found that the AST 


\section{Survival of Balb/c mice with NK/Ly lymphoma}

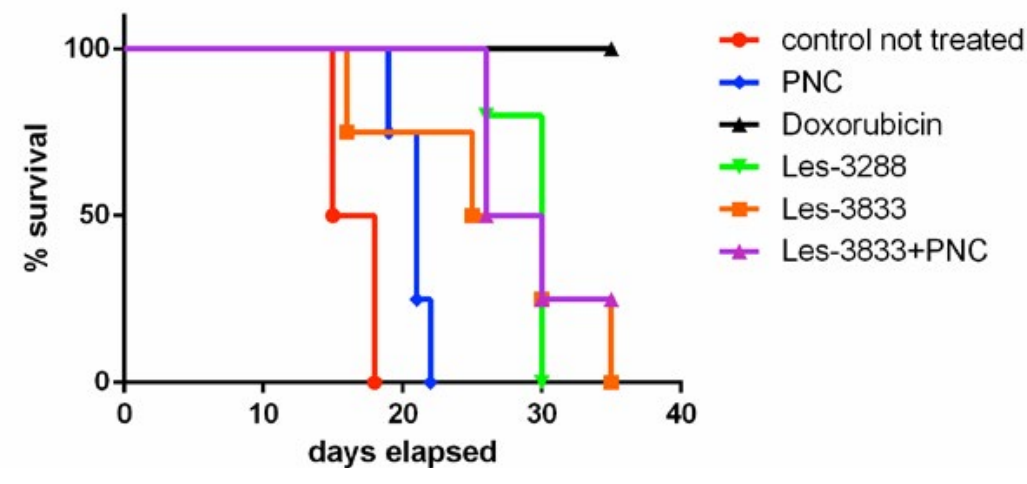

Fig. 3. Survival of mice bearing NK/ Ly lymphoma treated with Doxorubicin $(1 \mathrm{mg} / \mathrm{kg}$ of body weight), compounds Les-3288 $(5 \mathrm{mg} / \mathrm{kg}$ of body weight), Les-3833 (2.5 mg/kg of body weight) and Les-3833+PNC complex (1 mg of Les-3833/kg of body weight).

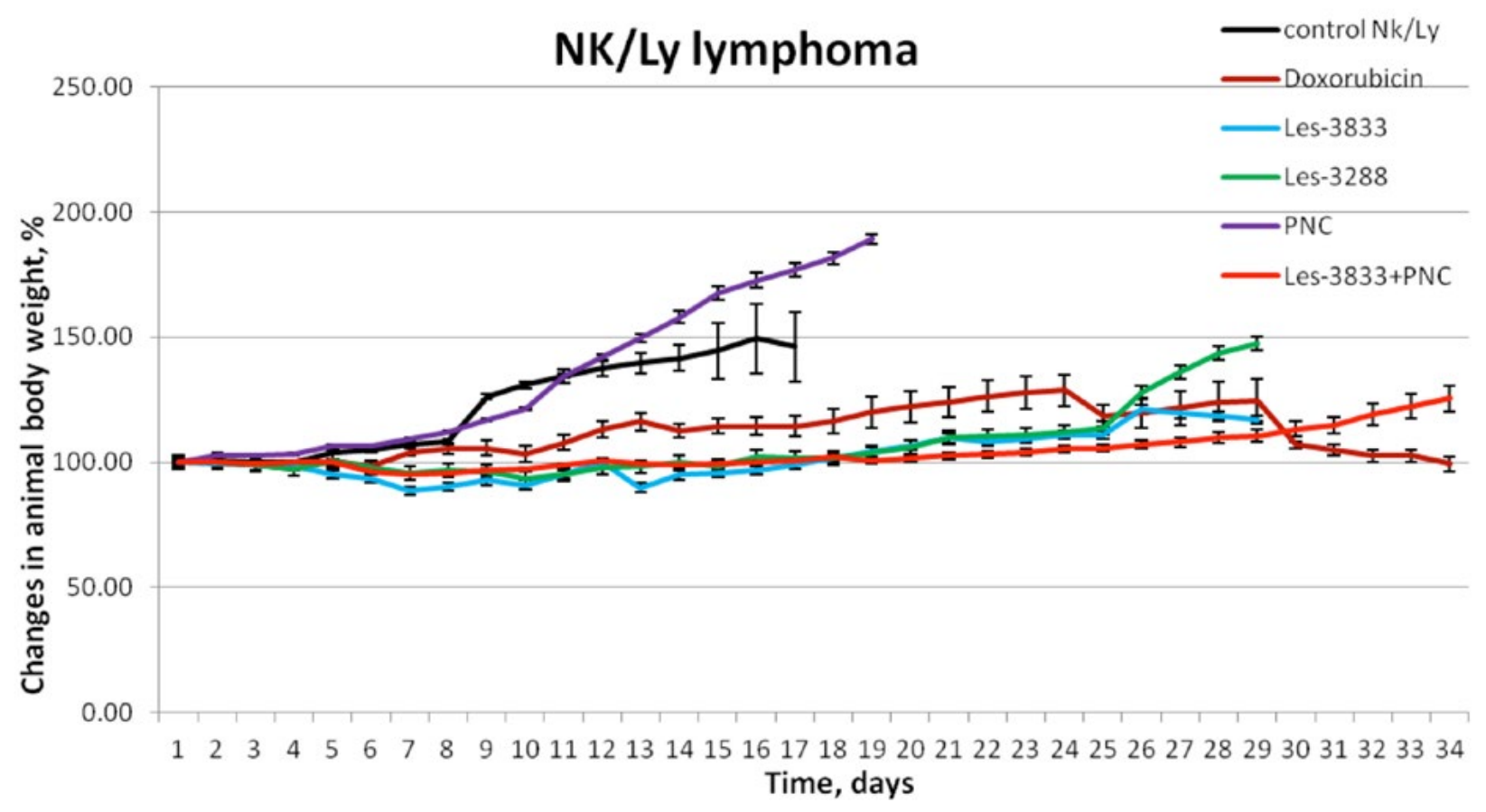

Fig. 4. Tumor grows in mice bearing NK/Ly lymphoma treated with Doxorubicin ( $1 \mathrm{mg} / \mathrm{kg}$ of body weight), compounds Les-3288 (5 mg/kg of body weight), Les-3833 (2.5 mg/kg of body weight) and Les-3833+PNC complex (1 mg of Les-3833/kg of body weight). Arrows indicate time of drug application.

activity increased in mice with lymphoma during 21 days by more than 2 times (Fig. 5). Doxorubicin increased the activaty of AST in blood of mice by more than 2 times on the $21 \mathrm{st}$ day of treatment, indicating the cardiotoxic effect, whereas the AST activity at the treatment with Les-3288 and Les-3833 compounds with PNC did not increase significantly.

The activity of ALT as the main liver enzyme increased under the influence of all an- 



Fig. 5. Activity of aminotransferases - AST and ALT, and the de Ritis coefficient in blood serum of NK/Ly lymphoma bearing mice treated with Doxorubicin $(1 \mathrm{mg} /$ $\mathrm{kg}$ of body weight), compounds Les-3288 (5 mg/ $\mathrm{kg}$ of body weight), Les-3833 (2.5 mg/kg of body weight) and Les-3833+PNC complex (1 mg of Les-3833/kg of body weight) for 14 days and 21 days. $* P<0.05$; **P $<0.01$; $* * * P<0.001$ (difference in comparison to the control).

titumor drugs during 21 days of treatment. (Fig. 5), and in the case of free compounds, the ALT activity rises more than 2 times, while free PNC and Les-3833 with PNC slightly increase the activity of this enzyme.

The de Ritis ratio was shown to be lower in blood serum of the NK/Ly lymphoma-bearing mice and after the treatment of Les-3288 and Les-3833 in free form. Les-3833+PNC complex did not affect the de Ritis coefficient for 21 weeks of treatment (Fig. 5). A reduction of de Ritis ratio indicates the hepatotoxic effect of the studied derivatives.

Thus, although doxorubicin, Les-3288, and Les-3833 demonstrated similar tumor treatment effects, the enzyme-linked liver damage (aspartate and alanine-aminotransferase) was less affected by these 4-thiazolidinone derivatives than doxorubicin. The treatment with Les$3833+$ PNC complex showed less toxic effect. 
Cytological indicators of toxic effects of 4-thiazolidinone derivatives(Les-3288 and Les-3833) and Doxorubicin (positive control) in mice bearing $N K / L y$ lymphoma

The studied antitumor agents caused adverse side effects towards the hematopoietic system. Doxorubicin and Les-3833 induced a severe anemia, significantly reducing the number of red blood cells on the 14th day, while Les-3833 with PNC were not so toxic, and the number of erythrocytes stayed normal during 21 days of the mice treatment (Fig. 6). The growth of NK/Ly lymphoma led to an increase in the leukocytes' number after 21 days more than 2 times, while all studied anticancer drugs significantly reduced that number on the 14th day, but increased on the 21st day after lymphoma inoculation (Fig. 6).

Leukocytes play an important role in human immune system, and most influences can change the number of leukocytes. The family of leukocytes is comprised of lymphocytes, monocytes, eosinophils, basophils, and neutrophils. These five types of leukocytes can be distinguished by their cytoplasmic granules, staining properties of the granules, the size of a cell, the proportion of nuclear to cytoplasmic material, and the type of nucleolar lobes [17].

The development of lymphoma NK/Ly in mice significantly increased the number of segmented nuclei leukocytes on the 14th and 21 st day after tumor inoculation; the studied anticancer drugs did not change this level during 14 days, but after 21 days the compound Les-3288 increased the number of segmented nuclei leukocytes (Fig. 7). Free PNC and its complex with Les-3833 stabilized with amphiphilic polymer in water system significantly increase the number of segmented nuclei leukocytes within 21 days. Both doxorubicin and
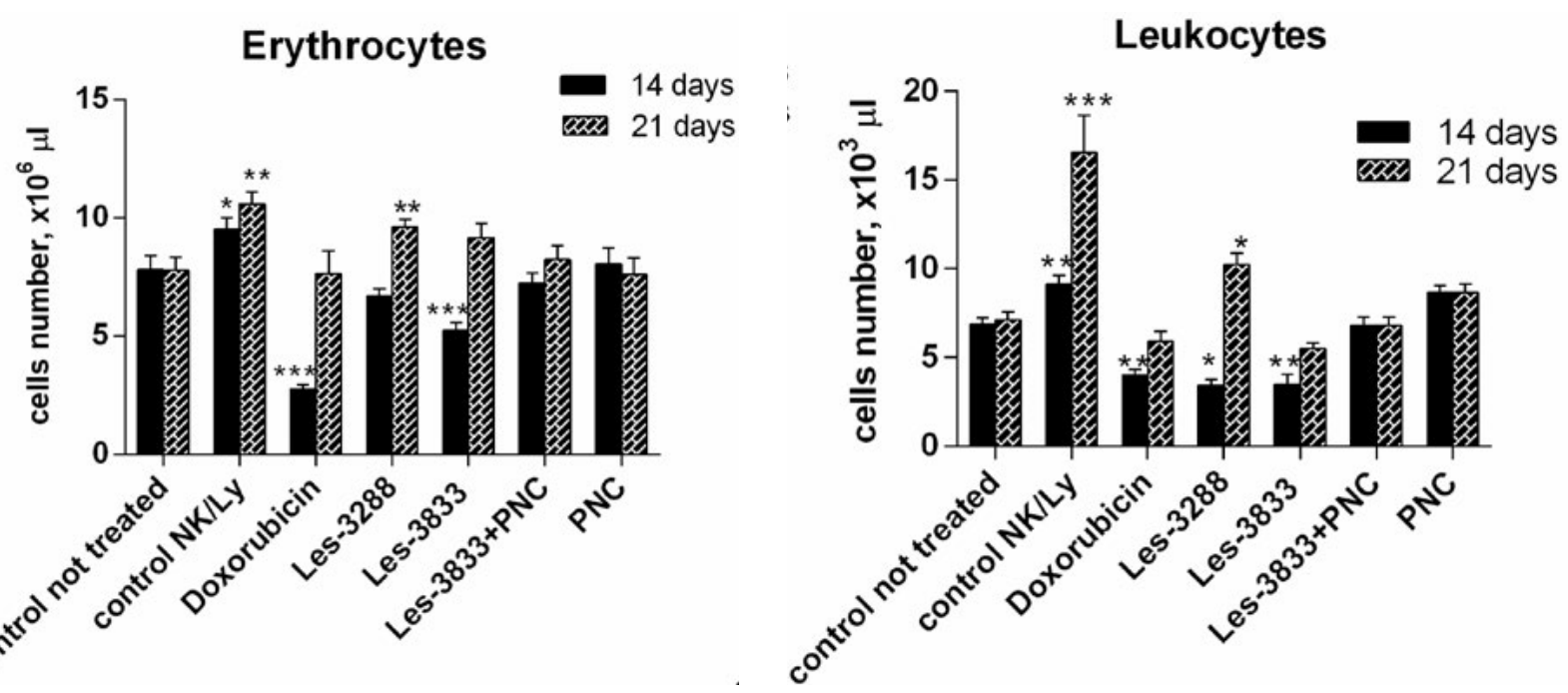

Fig. 6. The number of erythrocytes and leukocytes in NK/Ly lymphoma-bearing mice treated with Doxorubicin (1 mg/ $\mathrm{kg}$ of body weight), compounds Les-3288 (5 mg/ $\mathrm{kg}$ of body weight), Les-3833 (2.5 mg/kg of body weight) and Les$3833+$ PNC complex ( $1 \mathrm{mg}$ of Les-3833/kg of body weight) on the $14^{\text {th }}$ and $21^{\text {th }}$ day after tumor inoculation. $* P<0.05$; $* * P<0.01 ; * * * P<0.001$ (difference in comparison to the control). 


\section{segmented nuclei leukocytes}

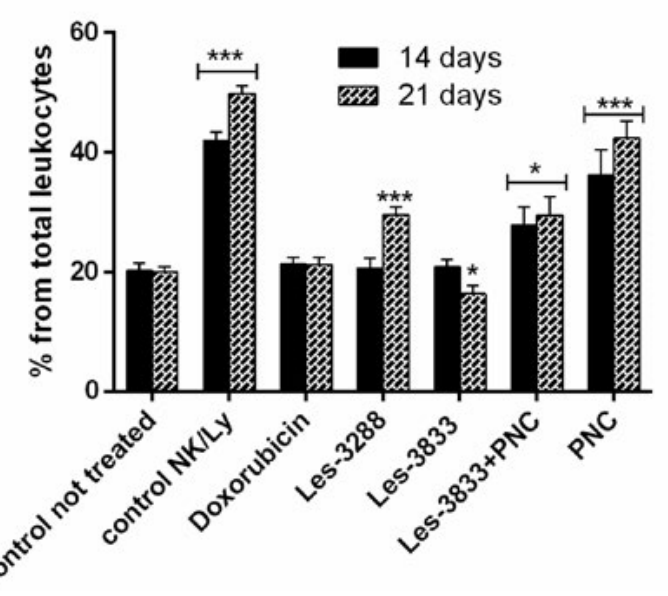

small lymphocytes

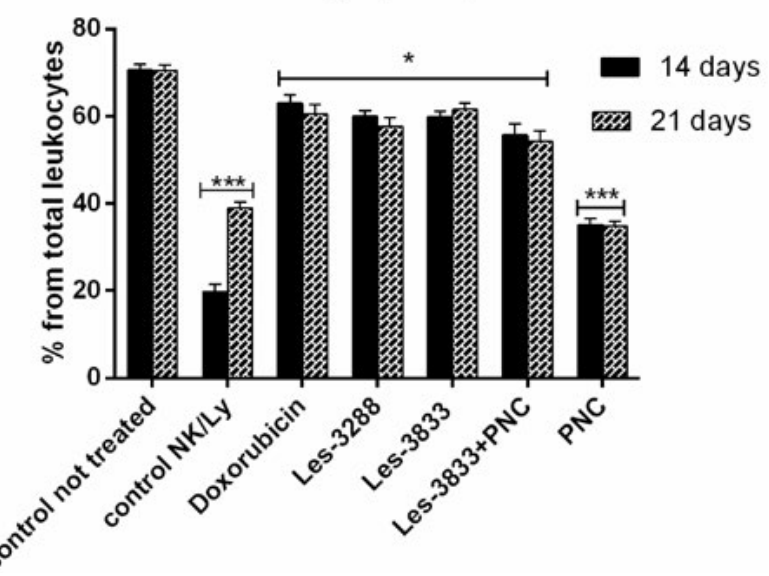

monocytes

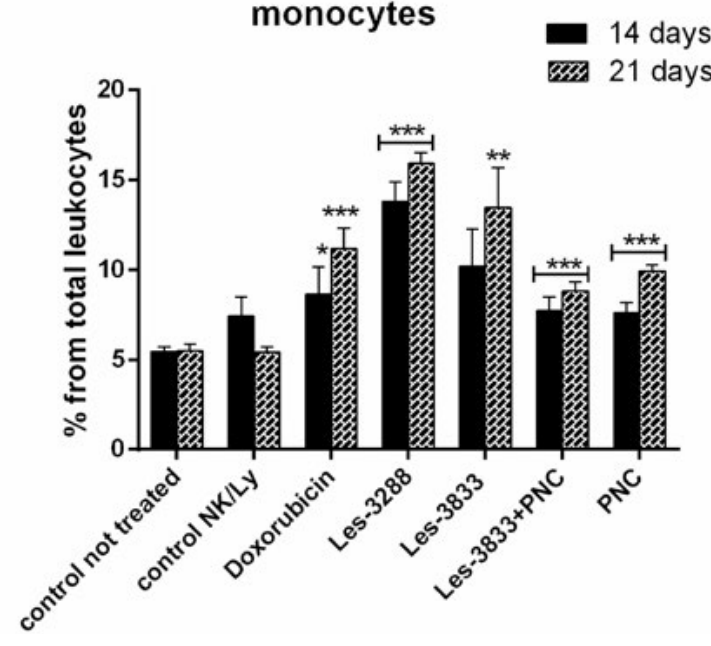

ring-shaped nuclei leukocytes

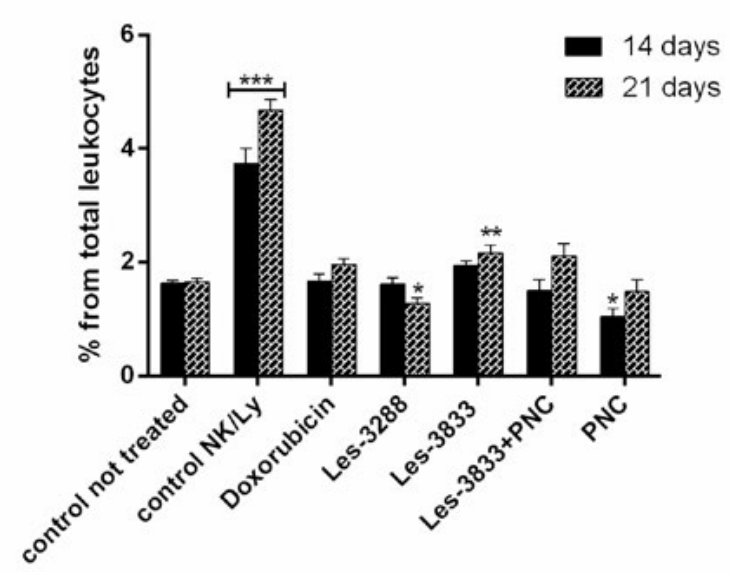

big lymphocytes

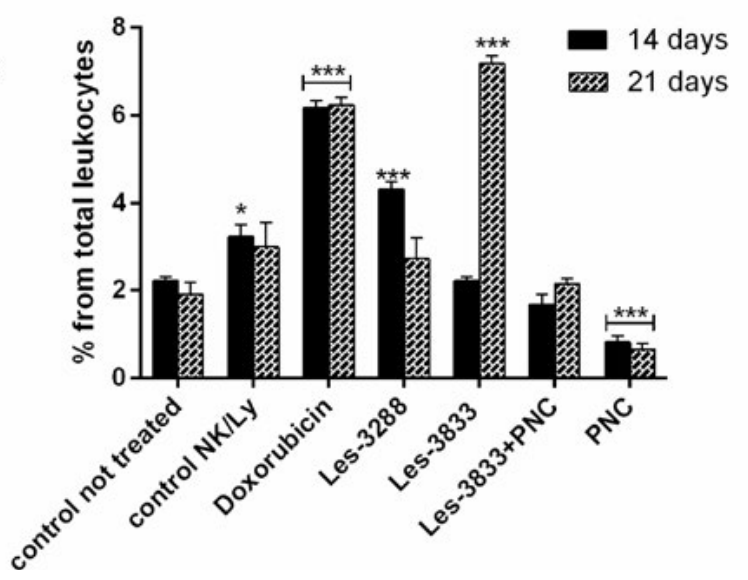

Fig. 7. Changes in leukogram in NK/Ly lymphoma bearing mice treated with Doxorubicin $(1 \mathrm{mg} / \mathrm{kg}$ of body weight), compounds Les-3288 (5 mg/kg of body weight), Les-3833 (2.5 mg/kg of body weight) and Les-3833+PNC complex ( $1 \mathrm{mg}$ of Les-3833/kg of body weight) on the $14^{\text {th }}$ and $21^{\text {th }}$ day after tumor inoculation. $* P<0.05$; ${ }^{* *} P<0.01$; ***P $<0.001$ (difference in comparison to the control). 
applied 4-thiazolidinone derivatives normalized the number of blood ring-shaped lymphocytes that were significantly increased after 14 and 21 days by the lymphoma growth (Fig. 7).

Lymphocytes are the major cellular components of the immune system, which are formed in the bone marrow and active in the lymphoid tissue. The main function of lymphocytes is the recognition of an antigen and the adequate immunological response of the organism. The number of small lymphocytes (T-lymphocytes and B-lymphocytes) is an important indicator that rapidly significantly decreased by $72 \%$ after 14 days in mice bearing NK/Ly lymphoma compared to the control animals. Although doxorubicin and 4-thiazolidinone derivatives reduced the number of small lymphocytes by $15 \%$, free PNC much more decreased it by $50 \%$ (Fig. 7). Doxorubicin significantly increased the number of big lymphocytes by 2.8 times, but Les-3288 increases their number by 1.9 times for only 14 days, and Les-3833 - by 3.8 times after 21 days of the experiment. However, under the influence of the water based complex Les-3833+PNC stabilized with amphiphilic polymer, the number of big lymphocytes does not change, compared to the control, and free PNC reduces their number by $63 \%$ (Fig. 7).

Monocytes belong to a system of phagocytic mononuclear cells that remove dead and damaged cells, denatured protein, and antigenantibody complexes from the body. Monocytes, that penetrate to blood from parenchymal organs and tissues, are formed by the macrophages, professional phagocytes that participate in the immune response of the organism, as well as phagocytes that destroy damaged cells in the organism. The investigated deriva- tives and Dox caused monocytosis in the treated tumor-bearing animals, while the water based complex Les-3833+PNC stabilized with amphiphilic polymer and free PNC did not affect the number of monocytes to the extent as free Les-3288 and Les-3833 did. However, the influence of the anticancer drug on large granular lymphocytes was different than the effect of complex Les-3833+PNC (Fig. 7).

\section{Discussion}

In this study, we addressed three principal problems of the anticancer chemotherapy: 1) low effectiveness of treatment with many anticancer drugs; 2) severe negative side effects that accompany the action of these drugs; 3 ) poor water solubility of some anticancer drugs and of numerous new experimental substances with the anticancer activity. As noted, many effective anticancer agents produce adverse side effects that limits considerably their use in clinics [2]. Earlier, we have found that the potent antitumor agents (Les-3288, Les-3833, Les-3882) were less toxic towards experimental animals (laboratory rats) when they were coated and stabilized with a synthetic polymeric carrier and used for treatment in the water based system [18-20]. It was evidenced by the results of measuring the biochemical parameters (the activity of aminotransferases and their ratio known as the De Ritis coefficient) of the toxic action (cardio-, hepato- and nephrotoxicity) of these derivatives in comparison with the action of doxorubicin [18-20]. Thus, the binding of antitumor agent with the PNC and its application in the form of water stable delivery system reduced its toxic effects in the experimental animals, compared to the action of these substances in a free form [18-20]. 
Taking into account the advantage of the experimental animal model (mice), we got a chance of counting specific blood cells such as erythrocytes, neutrophils and various types of lymphocytes in blood of the treated animals. In general, the NK/Ly lymphoma-bearing mice treated with Les-3833 and Les-3288 compounds stayed alive for more than 30 days, comparing to the control (untreated) animal that died in 18 days. The behavior indicators of the treated mice suggest much better life quality comparing to that of the mice treated with doxorubicin.

Positive effects of treatment by the studied 4-thiazolidinone derivatives correlated well with a pattern of changes in the number of erythrocytes and specific immune cells such as small lymphocytes (T-lymphocytes and B-lymphocytes), segmented nuclei lymphocytes and ring-shaped nuclei lymphocytes. While the doxorubicin induced a rapid (14 days) decrease in the number of red blood cells that even exceeded such decrease caused by tumor growth in mice, Les-3833 and Les3288 compounds did not induce such anemia effect.

NK/Ly lymphoma growth induced leukocytosis in the tumor-bearing mice that was well seen on the $21^{\text {st }}$ day after tumor inoculation. All agents used in this study - Les-3833 and Les-3288 compounds and doxorubicin (positive control) - significantly decreased tumorinduced leukocytosis, and a similar character of action was characteristic for segmented nuclei leukocytes and ring-shaped nuclei leukocytes as indicators of tissues damage [21, 22]. However, tumor growth was shown to decrease significantly the number of small lymphocytes which provide protection against the action of antigens and toxic agents. Both doxorubicin and Les-3833 and Les-3288 compounds normalized their number in blood of the experimental animals. At the same time, the number of big lymphocytes that are responsible for the development of antibodies and the number of monocytes carrying out phagocytosis and participating in the formation of specific immunity were not affected significantly by the NK/Ly lymphoma growth, while Les3833 and Les-3288 compounds and doxorubicin increased considerably the number of both these cell types. Such character of changes in the number of big lymphocytes and monocytes under the action of studied agents suggests the role of the immune system during treatment $[17,21]$.

For studying drug-induced morphological changes in the treated tumor cells, we have conducted a series of experiments in vitro. It was found that the pro-apoptotic and pro-necrotic changes induced by Les-3833 and Les3288 compounds in the rat glioma cells of C6 line were less pronounced than such changes induced by doxorubicin. It can be suggested that the treatment with these agents stabilized by the synthetic PNC in water preparations provided a protection of the treated glioma cells from the necrotic changes.

We have found that using PNC with 4-thiazolidinone derivatives - Les-3288 and Les3833 enhanced the pro-apoptotic action of these compounds. In another study [23], we have demonstrated that the induction of apoptosis by Les-3288 compound was not accompanied by ROS induction, opposite to the action of Dox and Les-3833. Thus, high antitumor activity of Les-3288 together with its low general toxicity in treated organism shown in 
the NK/Ly lymphoma-bearing mice suggest anticancer potentials of this experimental drug, especially in the water based complex with polymer carrier that enhances the anticancer efficiency.

\section{Conclusions}

novel 4-thiazolidinone derivatives Les-3288 and Les-3833 demonstrated their ability to suppress the growth of NK/Ly lymphoma grafted to BALB/C mice that leads to an increase in life longevity of the treated tumorbearing animals. The action of these compounds are accompanied by much less negative side effects evaluated by measuring the activity of blood serum aspartate and alanine aminotransferases, as well as red blood and white blood cell counts in the treated mice. The water based complex Les-3833+PNC stabilized by the amphiphilic polymer provided enhancement of the antitumor effect in vivo.

Funding. This work was partially supported by Lviv National Medical University (LK, RL, BZ), National Academy of Sciences of Ukraine (NS, OK, RS), and National University "Lviv Polytechnic" (NM, AZ).

Ethical Approval. This study was approved by Ethical Committee of Danylo Halytsky Lviv National Medical University, Protocol N4 from 18.04.2016.

Authorship Declaration. LK contributed to the conception of the study and interpretation of data, drafted the manuscript. NS and LK were responsible in studies of combined action of doxorubicin and 4-thiazolidinone derivatives on NK/Ly lymphoma on mice, analysis of blood formula of animals, ALT/AST measurements. OK conducted the cytomorphological study of cell damage using light and fluorescent microscopy. $\mathrm{MN}$ and $\mathrm{AZ}$ were responsible for synthesis of the amphiphilic polymer and formulation and development of stable water preparations of Les-3833 coated and stabilized with polymeric carrier. RL and $\mathrm{BZ}$ were responsible for design and synthesis of Les-3288 and Les-3833; and revised the manuscript. RS contributed to the conception of the study and interpretation of data; revised the manuscript.

Competing interests. All authors have completed the Unified Competing Interest form at www.icmje.org/coi_disclosure.pdf (available on request from the corresponding author) and declare: no support from any organization for the submitted work; no financial relationships with any organizations that might have an interest in the submitted work in the previous 3 years; no other relationships or activities that could appear to have influenced the submitted work.

\section{REFERENCES}

1. Elmore S. Apoptosis: a review of programmed cell death. Toxicol Pathol. 2007;35(4):495-516.

2. Savjani KT, Gajjar AK, Savjani JK. Drug solubility: importance and enhancement techniques. ISRN Pharm. 2012;2012:195727.

3. Narvekar M, Xue HY, Eoh JY, Wong HL. Nanocarrier for poorly water-soluble anticancer drugs--barriers of translation and solutions. AAPS PharmSciTech. 2014;15(4):822-33.

4. Feng $R$, Zhu $W$, Teng F, Liu N, Yang F, Meng $N$, Song $Z$. Poly(ethylene glycol) amphiphilic copolymer for anticancer drugs delivery. Anticancer Agents Med Chem. 2015;15(2):176-88.

5. Khosroushahi AY, Naderi-Manesh H, Yeganeh $H$, Barar J, Omidi Y. Novel water-soluble polyurethane nanomicelles for cancer chemotherapy: physicochemical characterization and cellular activities. J Nanobiotechnology. 2012;10:2. 
6. Zhang J, Li S, Li X. Polymeric nano-assemblies as emerging delivery carriers for therapeutic applications: a review of recent patents. Recent Pat Nanotechnol. 2009;3(3):225-31.

7. Kim JY, Kim S, Pinal R, Park K. Hydrotropic polymer micelles as versatile vehicles for delivery of poorly water-soluble drugs. $J$ Control Release. 2011;152(1):13-20.

8. Bunker A. Poly(ethylene glycol) in drug delivery, why does it work, and can we do better? All atom molecular dynamics simulation provides some answers. Phys Procedia. 2012;34:24-33.

9. Min Y, Caster JM, Eblan MJ, Wang AZ. Clinical Translation of Nanomedicine. Chem Rev. 2015; 115(19):11147-90.

10. Havrylyuk D, Zimenkovsky B, Vasylenko O, Gzella A, Lesyk R. Synthesis of new 4-thiazolidinone-, pyrazoline-, and isatin-based conjugates with promising antitumor activity. $J$ Med Chem. 2012;55(20):8630-41.

11. Riabtseva A, Mitina N, Boiko N, Garasevich $S$, Yanchuk I, Stoika R, Slobodyanyuk O, Zaichenko A. [Structural and colloidal-chemical characteristics of nanosized drug delivery systems based on pegylated comb-like carriers]. Chem Chem Technol. 2012;6(3):291-5.

12. Riabtseva A, Mitina N, Grytsyna I, Boiko N, Garamus VM, Stryhanyuk H, Stoika R, Zaichenko A. Functional micelles formed by branched polymeric surfactants: Synthesis, characteristics, and application as nanoreactors and carriers. European Polymer Journal. 2016;75:406-22.

13. Geran RS, Greenberg NH, Macdonald MM, Schumacher AM, Abbott BJ. Protocols for screening chemical agents and naturalproducts against animal tumors and other biological systems. Cancer Chemother Rep. 1972;3:1-87.

14. Ronin VS, Utevsky NL. Textbook for classes on the methods of clinical laboratory investigations. 4th ed. Moscow: Medicine, 1989. 335 p.

15. Navarro VJ, Senior JR. Drug-related hepatotoxicity. N Engl J Med. 2006;354(7):731-9.

16. Ozer J, Ratner M, Shaw M, Bailey W, Schomaker S. The current state of serum biomarkers of hepatotoxicity. Toxicology. 2008;245(3):194-205.
17. Chan YK, Tsai MH, Huang DC, Zheng ZH, Hung $K D$. Leukocyte nucleus segmentation and nucleus lobe counting. BMC Bioinformatics. 2010;11:558.

18. Kobylinska L, Panchuk R, Skorohyd N, Senkiv Y, Heffeter P, Berger W, Boiko N, Mitina N, Zaichenko A, Lesyk R, Zimenkovsky B, Stoika R, Vari GS. Conjugation of anticancer drugs with novel PEGcontaining nanocarrier provides circumvention of drug-resistance mechanisms in vitro and protects of general toxicity in vivo. Biotech, Biomaterials and Biomedical. Chapter 3: Materials for Drug \& Gene Delivery. TechConnect Briefs. 2017;3:60-63.

19. Kobylinska LI, Havrylyuk DY, Ryabtseva AO, Mitina NE, Zaichenko OS, Lesyk RB, Zimenkovsky BS, Stoika RS. Biochemical indicators of hepatotoxicity in blood serum of rats under the effect of novel 4-thiazolidinone derivatives and doxorubicin and their complexes with polyethyleneglycol-containing nanoscale polymeric carrier. Ukr Biochem $J$. 2015;87(2):122-32.

20. Kobylinska LI, Havrylyuk DYa, Mitina NE, Zaichenko AS, Lesyk RB, Zimenkovsky BS, StoikaRS. Biochemical indicators of nephrotoxicity in blood serum of rats treated with novel 4-thiazolidinone derivatives or their complexes with polyethyleneglycol-containing nanoscale polymeric carrier. $U k r$ Biochem J. 2016;88(1):51-60.

21. Biermann H, Pietz B, Dreier R, Schmid KW, Sorg C, Sunderkötter $C$. Murine leukocytes with ring-shaped nuclei include granulocytes, monocytes, and their precursors. J Leukoc Biol. 1999;65(2):217-31.

22. Panchuk RR, Skorokhyd NR, Kozak YS, Lehka LV, Chumak VV, Omelyanchik SN, Gurinovich VA, Moiseenok $A G$, Stoika RS. Antioxidants selenomethionine and D-pantethine decrease the negative side effects of doxorubicin in NL/Ly lymphoma-bearing mice. Croat Med J. 2016;57(2):180-92.

23. Kobylinska LI, Boiko NM, Panchuk RR, Grytsyna II, Klyuchivska OY, Biletska LP, Lesyk RB, Zimenkovsky BS, Stoika RS. Putative anticancer potential of novel 4-thiazolidinone derivatives: cytotoxicity toward rat C6 glioma in vitro and correlation of general toxicity with the balance of free radical oxidation in rats. Croat Med J. 2016;57(2):151-63. 
Підвищення протипухлинної активності та зменшення негативних побічних ефектів у мишей з лімфомою NK/Ly, лікованих похідними 4-тіазолідинону у комплексі 3 полімерним наноносієм

Л. І. Кобилінська, Н. Р. Скорохід, О. В. Ключівська, Н. Є. Мітіна, О. С. Заіченко, Р. Б. Лесик, Б. С. Зіменковський, Р. С. Стойка

Мета. Визначити протипухлинну активність та цитологічні та ферментативні показники загальної токсичності 4-тіазолідинонових протипухлинних похідних (Les-3288, Les-3833) на моделі пухлини - лімфома NK/Ly, прищепленої мишам BALB/C. Методи. Мишам BALB/C імплантували асцитну лімфому NK/ Ly i лікували впродовж 14 днів 4-тіазолідиноновими похідними - Les-3833 (2,5 мг/кг ваги), Les-3288 (5 мг/ кг ваги), комплексом Les-3833 з полімерним наноноciєм Les-3833+PNC (2,5 мг/кг ваги) у воді, і доксорубіцином (1 мг/кг ваги), який використовували як позитивний контроль. Розвиток лімфоми контролювали шляхом вимірювання у мишей кількості асцитної рідини. Вплив досліджуваних похідних 4-тіазолідинону перевіряли впродовж 35 днів росту пухлини. Результати. У дослідної групи виявлено зниження кількості асцитної рідини з клітинами лімфоми, в той час як у нелікованих мишей контрольної групи виявлено збільшення кількості асциту в 1,5 рази. Похідні 4-тіазолідинону продемонстрували набагато меншу токсичність, а кількість еритроцитів залишалася нормальною після 21 дня лікування тварин. Розвиток лімфоми NK/Ly у мишей призвів до збільшення кількості нейтрофілів, тоді як досліджувані протипухлинні сполуки значно зменшили його. Досліджувані похідні 4-тіазолідинону не впливали на кількість лімфоцитів у крові тварин. Активність аспартатамінотрансферази та аланінамінотрансферази у сироватці крові підвищена на 14-й день лікування тварин і повертається до норми на 21-й день. Висновок. Нові 4-тіазолідинони Les-3833 та Les-3288 виявилися ефективними при лікуванні лімфоми NK/Ly, прищепленої мишам BALB/C. Вплив цих похідних призвів до менш виражених негативних побічних ефектів у лікованих мишей.

К л юч о в і с л о в а: 4-тіазолідинони, лімфома NK/Ly, миші BALB/C, клітини гліоми C6, апоптоз
Повышение противоопухолевой активности и уменьшение негативных побочных эффектов у мышей с лимфомой NK/Ly, леченных производными 4-тиазолидинона в комплексе с полимерным наноносителем

Л. И. Кобылинская, Н. Р. Скороход,

О. В. Ключивская, Н. Митина, А. С. Заиченко, Р. Б. Лесик, Б. С. Зименковский, Р. С. Стойка

Цель. Изучить противоопухолевую активность, цитологические и ферментативные показатели общей токсичности производных 4-тиазолидинона (Les-3288, Les-3833) на модели опухоли - лимфома NK/Ly, привитой мышам BALB/C. Методы. Мышам BALB/C имплантировали асцитную лимфому NK/Ly и в течение 14 дней лечили их производными 4-тиазолидинона - Les-3833 (2,5 мг/кг веса), Les-3288 (5 мг/кг веса), комплексом Les-3833 с полимерным наноносителем Les-3833+PNC (2,5 мг/кг веса) в воде, и доксорубицином (1 мг/кг веса), который использовали в качестве положительного контроля. Развитие лимфомы контролировали путем измерения у мышей количества асцитной жидкости. Общие токсические воздействия исследуемых производных 4-тиазолидинона контролировали в течение 35 дней роста опухоли. Результаты. У мышей обнаружено четкое снижение количества асцитной жидкости с клетками лимфомы, в то время как у мышей контрольной группы выявлено увеличение количества асцита в 1,5 раза. Производные 4-тиазолидинона продемонстрировали меньшую токсичность, а количество эритроцитов оставалась в норме после 21 дня лечения животных. Развитие лимфомы NK/Ly у мышей привело к увеличению числа нейтрофилов, тогда как исследуемые противоопухолевые соединения значительно уменьшили его. Исследуемые производные 4-тиазолидинона не влияли на количество лимфоцитов в крови животных. Активность аспартатаминотрансферазы и аланинаминотрансферазы в сыворотке крови повышена на 14-й день лечения животных и возвращается к норме на 21-й день. Выводы. Новые 4-тиазолидиноны Les-3833 и Les-3288 оказались эффективными при лечении лимфомы NK/Ly, привитой мышам BALB/C. Влияние этих производных привело к менее выраженныхм негативным побочным эффектам у леченных мышей.

К л юче в ы е с л о ва: 4-тиазолидиноны, лимфома NK/Ly, мыши BALB/C, клетки глиомы C6, апоптоз

Received 07.03.2018 